Available online at: $\mathrm{http} / / /$ proceeding.rsfpress.com/index.php/pss/index

LPPM UPN “Veteran" Yogyakarta Conference Series

Proceeding on Political and Social Science (PSS)

Volume 1 Number 1 (2020): 77-82

\title{
Creating Agricultural Product Innovations and Business Development: A Case in Farmer Women Group
}

\author{
Endah Wahyurini, Humam Santosa Utomo \\ Universitas Pembangunan Nasional Veteran Yogyakarta \\ E-mail address endah.wahyurini@upnyk.ac.id; E-mail address \\ humam.santosautomo@upnyk.ac.id
}

\begin{abstract}
The Covid-19 pandemic implies a decrease in family income, resulting in social problems such as unemployment and poverty. This study aims to describe the process of creating product innovation carried out by groups of women farmers by using the land around the house to grow vegetables and the challenges they face. The study was conducted on a group of female farmers in Bantul, Yogyakarta using a qualitative analysis approach. Data collection techniques used observation, in-depth interviews, and focus group discussions. The results of this study indicate that the crisis conditions and knowledge play an important role in the creation of innovation in agriculture. The diverse knowledge of the members creates new product and service innovation ideas. Universities, local governments, and industry play a role in encouraging the creation of innovation and the formation of joint ventures so that members get economic benefits. The women farmer groups have grown their roles, not only as social organizations but also in business organizations.
\end{abstract}

Keywords: agricultural product innovation, farmer women group, stakeholder

\section{INTRODUCTION}

This is an open access article under the CC-BY-NC license.

Almost all people have felt the consequences of the Covid-19 pandemic. Job loss or reduced family incomes are common problems faced by society. Family economic problems have implications for social problems such as unemployment and poverty. Women take on roles by taking advantage of opportunities in difficult times. One of their ideas is to use the yard around the house to grow vegetables. The produce of vegetables can be consumed and sold. They took the initiative to form a group of women farmers which was not only a social organization but also a business organization. This phenomenon is interesting to study further considering that previous studies were still limited.

This study aims to describe how the process of innovation is formed and the role of knowledge in finding product and service innovations. This study also analyzed the process 
of forming a women farmer group and the benefits of the group for its members. Apart from that, the role of the government and universities is also interesting to observe. Social support, especially from family, is also important to learn.

\section{LITERATURE REVIEW}

\section{II.1. State Innovation}

Innovation is important for companies because it is a source of company competitiveness (Battor \& Battor, 2010; Sivadas \& Dwyer, 2000). The company's competitiveness has implications for increased sales and profits. Innovation is shown by new products or product development that can increase product value so that you can compete with competitors. On the basis of an innovative company is a company that is able to create or develop products according to market tastes (Adler \& Shenbar, 1990). The results of scientific research play an important role in the process of creating innovation (OECD and Eurostat, 2005).

Agricultural innovation goes through various stages, including technology adoption, adaptation, and diffusion at the farm level, and to investigate the impact of agricultural policies on technological change, technical efficiency, and production intensification (Pisante et al., 2012). Innovations in agriculture, such as the use of different new technologies to meet different market demands. Innovation results in higher quality products in terms of size, shape, taste, and so on. Packaging innovation is also needed in protecting product quality and a more attractive appearance. Financing innovations result in lower costs so that companies can charge more attractive prices.

\section{II.2. The Role of Stakeholders}

The ability to innovate is not only influenced by farmers, but also by the surrounding environment (Porter et al., 2007). The Triple Helix innovation model encourages economic development (Etzkowitz and Leydesdorff, 1995). Government, academia, and industry play an important role in increasing the innovation and progress of small businesses. Sources of financing, increased knowledge, utilization of technology, and access to marketing are urgently needed (Yuwawutto et al. 2010). Therefore, an effective innovation system includes all relevant stakeholders. The government contributes to increasing agricultural product innovation through public research, infrastructure, and tax policies that have implications for small business operations (OECD, 2011).

Rangaa et al (2008) have identified the main reasons for the failure of collaborative roles in the triple helix, including the government's awareness of the problems of small companies, less visible government programs, overlapping bureaucracy, cultural differences, and language differences. Each party must have a strong commitment to innovation creation for small companies and business development. Innovation needs to be supported in order to generate financial benefits for small companies. Therefore, the managerial aspects, access to capital, and market access are needed by SMEs in developing their business. 


\section{RESEARCH METHODOLOGY}

This study used a qualitative approach involving 10 farmers from a group of women farmers in Bantul, Yogyakarta. They developed farms on the narrow land around their homes during the Covid-19 pandemic. The data source used is primary data using observation, in-depth interviews, and focus group discussion (FGD). Apart from the women farmer groups, information was also collected from the local government, universities, and industry. Triangulation was carried out to ensure that the data obtained were valid and consistent. Through FGD, the answers of each party can be confirmed. Answers from related parties are used to analyze the problems of this research.

\section{FINDING AND DISCUSSION}

\section{IV.1. Results Innovation Creation}

The Covid-19 pandemic has had a negative impact on family income. This situation spurs the members of the women farmer groups to make various breakthroughs in order to fulfill their daily lives. Before the pandemic, they worked in the fields to make ends meet, although the results were also unreliable. Their rice fields are not large, so the harvest is not sufficient for the family's needs. Innovations have been carried out in the following steps:

\section{IV.1.1. Brainstorming}

The women farmer group members held discussions with the college team's guidance in order to find a solution. They have almost the same problem, namely falling income during a pandemic. Women farmer group members have various educational backgrounds, knowledge, and experiences. Brainstorming is carried out in an effort to find ideas to develop agriculture so that it has greater economic benefits. Based on diverse knowledge, it is not difficult to come up with business ideas. They agreed to improve the function of the organization not only as a social function but also as a business function. Initially, the women farmer groups were only used to exchange knowledge related to agriculture and agricultural fairs. They began designing joint activities to collaborate on economic activity. They collect ideas for creating new agricultural products and services.

\section{IV.1.2. Idea Setting}

Various kinds of ideas from the members were analyzed and selected some ideas that really provide value for consumers and provide income for farmers. They decided to manage the narrow land around their house. The narrow land around the house can be used to grow vegetables so that they can be consumed by themselves and sold to consumers.

\section{IV.1.3. Determination of agricultural product innovation}

The product innovation created is organic vegetables. They grow various kinds of vegetables that are needed by the community. Organic vegetables are easier to grow in the yard around the house because the water used can be well controlled. Organic vegetables require different treatments and have different markets. Organic vegetables are usually sold in supermarkets and have middle to upper-class market segments or consumers who are sensitive to chemical fertilizers. Generally, organic vegetables are more expensive than non-organic vegetables. Organic vegetables grown in the yard around the house can reduce production costs so that 
they have higher competitiveness compared to competitors. Apart from vegetables, innovation is also in the form of processed foods made from organic vegetables.

\section{IV.1.4. Determine the sales service innovation}

Social restrictions have been put in place during the pandemic, so sales to vegetable outlets have been hampered. Online sales are the best choice by opening product information on social media, like Instagram, WhatsApp, Line, or other social media. Distribution is carried out directly to consumers who order and vegetable products are delivered directly to consumers' homes.

\section{IV.1.5. Product packaging innovation}

The packaging innovation is intended to maintain the quality of agricultural products while increasing product attractiveness. The packaging uses recycled paper so it is environmentally friendly and very affordable.

\section{IV.2 Business development}

The members of the Women's Farmers Group are not used to set up a well-organized business unit. The formation of a business embryo involves a team from universities as facilitators. A small company in the form of a cooperative has been formed, although it does not yet have a legal entity, it has started operating. The company structure is designed simply because it is still in the pilot stage. The company is headed by a director and two or three managers. The production manager is in charge of preparing organic vegetables according to market demand. In addition, the production manager also develops processed organic vegetable products, such as vegetable chips and ready-to-eat vegetables. Marketing managers are tasked with designing marketing strategies and carrying out sales to consumers. Marketing managers also design and manage online marketing thereby expanding the marketing area. The financial manager is in charge of managing funds so that they can support company operations.

\section{IV.3.Role of Local Government}

The government contributes significantly to creating innovation and developing business. The government provides flexible regulations for starting a business. In addition, the local government also provides guidance to farmer groups to find innovative ideas and develop institutions. The local government also provides exhibitions and culinary stalls to facilitate the sale of SMEs. The Bantul Regency Government organizes a culinary market around government offices and culinary centers every two weeks. The village government also provides sales facilitation for nearby SMEs with cheap rental fees.

\section{IV.4.Industry Role}

The banking industry has provided credit facilities to members of women farmer groups at low-interest rates. In addition, through the CSR program, several government banks have supported the activities of women farmer groups in facilitating agricultural facilities and sales facilities. For example, providing a sales place and assisting in the production process.

\section{IV.5.Role of Higher Education}

Higher education has human resources who can help the difficulties faced by women farmer groups. One of the universities participating in the innovation development and business 
development program is the University of Pembangunan Nasional "Veteran" Yogyakarta. The college team was involved starting from analyzing the situation, finding concrete problems faced by the community, looking for solutions together, finding alternative solutions, choosing the most possible solutions, finding product innovations, holding training, accompanying the formation of business units, conducting business assistance, provide facility assistance, and conduct joint evaluations. Higher education also assists in the management of business units that have been formed until they are considered independent. Lecturers and students are involved in community service programs that are carried out regularly and continuously.

\section{IV.6. Challenges Faced}

The challenge faced is business sustainability. The business units that have been established are able to provide economic benefits for members. Some members who have been successful maybe self-sufficient so that the number of members of this business organization will decrease. In addition, the sharing of benefits and risks is a challenge. Financial reports that are not transparent enough lead to dissatisfaction with members who may resign. Therefore, a professional business organization with good governance is needed.

\section{CONCLUSION AND FURTHER RESEARCH}

Agricultural product innovation begins with the problems experienced by the community during the pandemic. The use of yards around the house is one agricultural innovation to increase agricultural production. Organic agricultural products are also a form of product innovation that consumers are interested in. Various organic-based agricultural processed foods have also been made by women farmer groups. The innovation of vegetable product packaging by utilizing recycled paper is intended not only to protect product quality but also to increase product attractiveness.

The role of the women farmer groups has grown. Initially, this group was only intended to exchange knowledge and experience, but now it has developed into business collaboration by setting up production cooperatives. Support from the government, industry, and universities increases the speed of women farmer groups in realizing business development.

This study has several limitations. First, the women farmer groups taken in this study have not been able to represent groups of women farmers in the Bantul district. This study takes a case from one farmer group so that the next study is expected to expand the research to other farmer groups. Second, this research has not used quantitative indicators because this research uses a qualitative approach. Future research is expected to complement quantitative research so that a more comprehensive understanding will be obtained. The next research opportunity is also open to finding out the influence of knowledge on innovation creation with the role of stakeholders as moderators. This study makes a practical contribution to women farmer groups in developing innovative products and services. This study is also useful for stakeholders in carrying out an effective mentoring program.

\section{REFERENCE}

Battor, M., \& Battor, M. 2010. The impact of customer relationship management capability on innovation and performance. Journal of Marketing Management, 26(9-10), 842-857. 
Sivadas, E., \& Dwyer, F. R. 2000. An Examination of organizational factors influencing new product success in internal and alliance-based processes. Journal of Marketing, 64(1), 31 49.

Adler, P. S., \& Shenbar, A. 1990. Adapting your technological base: The organizational challenge. Sloan Management Review, 25, 25-37.

OECD, Eurostat, 2005. Oslo manual: guidelines for collecting and interpreting innovation data. OECD Publ., Paris, France

Pisante, Fabio Stagnari, Cynthia A. Grant. 2012. Agricultural innovations for sustainable crop production intensification Michele. Italian Journal of Agronomy 2012; volume 7:e40

Porter ME, Ketels C, Delgado M, 2007. The microeconomic foundations of prosperity: findings from the business. The global competitiveness report 2007-2008. World Economic Forum

Etzkowitz, H. and Leydesdorff, L. 1995 'The Triple Helix: university-industry-government relations. A laboratory for knowledge-based economic development', EASST Review. European Society for the Study of Science and Technology, Vol. 14, No. 1, pp.18-36.

Yuwawutto, S., T. Smitinont, N. Charoenanong, N. Yokakul, S. Chatratana, and G. Zawdie, 2010. "A Triple Helix Strategy for Promoting SME Development: The Case of a Dried Banana Community Enterprise in Thailand," Ind. High. Educ., 2010.

OECD, 2011. Fostering productivity and competitiveness in agriculture, OECD Publ., Paris, France

Rangaa, L.M., Joost Miedemab, and René Jorna. 2008. Enhancing the innovative capacity of small firms through triple helix interactions: challenges and opportunities Technology Analysis \& Strategic Management Vol. 20, No. 6, November 2008, 697-716 